\title{
New Technologies of Studying in the Process of Professional Training of Future Specialists
}

\author{
Pirmaganbet Ishanov \\ Doctor Ph.D., Professor, Karaganda State University named after E.A.Buketov \\ ishanov65@mail.ru
}

\section{Gulya Khairova}

Candidate of Philological Sciences, Associate Professor, Karaganda State University named after E.A.Buketov g.khairova@mail.ru

\section{Rustemova Zhanar}

Candidate of Philological Sciences, Associate Professor, Karaganda State University named after E.A.Buketov

Zhandos Yermembetov

Master of Pedagogical Sciences, Karaganda State University named after E.A.Buketov

\section{Doi:10.5901/mjss.2015.v6n6s4p260}

\begin{abstract}
This article addresses the problem of training in technical and vocational education through modern training techniques based on the principle of the succession of content disclosed such requirements as the systematic acquisition of new teaching methods, and innovative teaching techniques that provide professional knowledges.

Keywords: Technical and vocational education, new teaching methods, process of training, pedagogical technology, modernization of education.
\end{abstract}

\section{Introduction}

Professional education in the Republic of Kazakhstan comes to higher technological level as there is a demand for search of new technologies of training that is totally connected, first of all with the refusal of traditional training, with the idea of technological effectiveness and innovation of process of training of future experts of various profile and direction.

So, in the Law "About Education" of the Republic of Kazakhstan as a priority problem of an education system introduction and effective use of new technologies of training, including credit, remote, information-communicative, promoting fast adaptation of professional education to the changing requirements society and labor market" is noted" (The Law "About Education". Astana. 2007).

Updating of the technological direction in professional pedagogics isn't accident. The pedagogical science looks for ways of achievement if not absolute, then high and stable result in pedagogical process of professional school. Reacting to all changes of social conditions and requirements, the professional pedagogics seeks to create everything new and new approaches, methods and forms. As it is noted that: "In the conditions of variable education various pedagogical systems and consequently, and the most various models of training, are used own approaches to the organization of pedagogical process, original technologies of studying are developed, own pedagogical technologies are developed too" (Chernilevsky, 2002).

\section{Methodology}

Teachers-researchers give also other characteristics of pedagogical technology. G. K. Selevko specifies in his own work that the pedagogical technology functions and as the science investigating the most rational ways of training and as system of the ways, the principles and regulative applied in training and as real process of training (Selevko, 1998). 
Results of the carried-out treatments of the concept "pedagogical technology", consideration of essence of the studied problem, identification of appointment and the qualities and characteristics ordered it allow to claim that pedagogical technologies in professional education were and remain the main the mechanism of the effective organization and implementation of process of training of specialists.

World pedagogical science being affected by scientific and technical progress and integrating achievements of psychology, sociology of the theory of management and other sciences, constantly is in the phrase of active innovative processes. Introduction of progressive pedagogical technologies in process of training of specialists is also caused by demand of growth of consciousness trained, to acquisition of skills of logical, independent thinking and the argument, development not only own, but also joint point of view that in turn to successful assimilation of a training material.

\section{Research and Results}

Of course, without accurately formulated requirements to future experts, without comprehensively thought over selection the maintenance of a training material on the basis of continuity, sequences, logicality and a continuity, it is impossible to reach the final purpose preparation of the highly qualified specialist. For this reason to teachers of establishments of professional education a number of requirements which performance will promote in full improvement of quality of training of specialists in professional education are shown. One of the main requirements can allocate systematic mastering new methods of training taking into account the contingent with trained, innovative and pedagogical technologies providing the necessary and sufficient knowledge for further professional activity and also incorporating system of information the expert, necessary for preparation meeting modern the requirements of the state, society and the employer.

The account and implementation of such requirements in our opinion will affect informative activity of future experts, their educational and professional motivation, an individualization and technologization of pedagogical process and, finally, improvement of quality of training of future experts in technical and professional education, and also modernization of this education level.

Modern modernization of technical and professional education is caused by need of high-quality break for training of the technical and serving work in connection with growth of scale and complexity of problems of industrial and innovative development of Kazakhstan in the conditions of globalization and transition to economy of knowledge with pervasive influence of information technologies and the growing competition in internal and external labor markets. Creation of highly effective national system of technical and professional education is one of major factors of ensuring sustained economic growth of the country, social stability of the Kazakhstan society, the mechanism of maintenance of steady employment of youth.

For the purpose of modernization of system of secondary professional education the state program of development of technical and professional education to the Republic of Kazakhstan for 2008-2012 is developed for providing branches of economy and employers with qualified specialists of the technical and serving work with competitive skills and sufficient potential, the Ministry of Education and Science of the Republic of Kazakhstan.

The carried-out analysis of a condition of system of technical and professional education shows considerable reduction of a network of professional lyceums (schools) number of professional lyceums (schools) makes only $71 \%$ of number of professional lyceums (schools) in 1991, first of all today number of professional lyceums (schools) and colleges preparing shots on technical and technological specialties (from 1991 to 2000 reduction of quantity such educational an institution made respectively $59 \%$ and $28 \%$ ). Practically all educational institutions of technical and professional education work with use morally and physically outdated equipment (A state program of technical and professional education. Astana, 2008).

In this regard vocational training of experts has to be considered in a framework of process of continuous professional education. The continuity of education is provided due to all-round development of the personality at all stages of her activity: forward enrichment of its opportunities in more and more full realization of forces and abilities, professional and common cultural growth. It means the unity of all education system and a free access to them.

In professional pedagogics continuous education is considered as the focused its constitution new humanistically. On the basis of it the systematizing factor of continuous education is considered its integrity the defining feature of a development of education and its contents.

The content of education is a welfare phenomenon and the integrative system reflecting part of cumulative social experience. The problem of formation of the content of education was actual during all historical eras. The education system which resolves issues of for what, whom, to that and how to train and bring up is inherent in a certain historical stage of development of society.

In this regard the analysis of the maintenance of educational programs and educational and methodical providing 
shows that they not fully meet the requirements of employers expressing changes in labor market, requirements trained, seeking to receive demanded skills and competences. In our opinion, the main obstacle to improvement of quality of educational process in professional colleges is the low level of educational and methodical providing, deficiency of modern educational literature, especially on special disciplines in a state language, lack of the institutions which are purposefully engaged in scientific and methodical providing (Bespalko, 1989).

From the position of professional pedagogics the content of education is recorded in documents - the state educational standard, the training program of the corresponding course, etc. Thus the social objects set for system of professional education on modern training of specialists are embodied in the content of education

That is a consequence of the fact that today in Kazakhstan the content of training of specialists has to be formed on the basis of the state educational standards, including its humanization, training and education of experts on the basis of the principles of independence, a support on rich spiritual and intellectual potential of the people and universal values follows. The special attention in pedagogical process of professional colleges has to be paid to the personality trained, to development of an education cult in it and knowledge, creative activity, aspiration to formation of independence in the course of cognitive activity.

Shift of the emphases in educational process on priority of value of the personality trained, transition to the subject - to the subject relations, the persons aimed at development of creative creativity and formation of its readiness for development of the creative potential, focus attention to processes of self-improvement, development and selfdevelopment of the creative identity of future expert, and the teacher.

So, the creative potential of the teacher is characterized by the volume and depth of various knowledge, abilities, professional and personal qualities and intellectual and creative abilities. This unity creates opportunity to creative selfrealization in professional activity defines optimum ways of improvement of quality of training of specialists on average professional education.

Proceeding from it professional colleges on the equipment, selection of teaching staff, the organization of process of training have to be educational institutions one and more modern professions and specialties representing possibility of mastering, and also acquisition of profound theoretical knowledge and formation of practical skills by means of modern educational technologies (Kashlev, 2002).

In this case an important role plays professional qualities of the modern teacher of professional education. As the main professional qualities of the teacher we mark out diligence, working capacity, discipline, responsibility, ability to set the object, to choose ways of its achievement, organization, persistence, systematic and systematic increase of the professional level, aspiration constantly to increase quality of the pedagogical work in the field of modern technologies of training, etc.

Through these requirements the teacher is realized as the expert who is carrying out the duties in system of relations of production. Before our eyes there is a noticeable transformation of educational institutions in the production establishments providing "educational services" to the population where plans work, contracts the competition - the inevitable satellite of the market relations develops. In these conditions special importance is gained by human qualities of the teacher which become professionally significant prerequisites of creation of the favorable relations in teaching and educational process of technical and professional education, and also creation of conditions for implementation of pedagogical activity.

Pedagogical activity of the teacher of professional educational institution - the professional activity directed on creation in pedagogical process of an average link of optimum conditions for the training, development and selfdevelopment of the personality which is trained and a choice of opportunities of free and creative self-expression. Successful implementation of pedagogical activity demands the high level of professional consciousness of the teacher, his orientation on training and education of future experts, mastering by it pedagogical technology, pedagogical skill and pedagogical equipment (Grebyonkina, Antsiperova, 2000).

Besides pedagogical activity is considered as process of the solution of an uncountable number of pedagogical tasks. The main pedagogical objective - an ultimate goal of training and education on average vocational training, is solved the teacher by transformation of training of future experts to self-training (self-education), external regulation of their actions and acts in self-control.

Thus, the teacher will transform the pedagogical purposes to the psychological purposes trained, and it is possible only on condition of understanding by the teacher of the general and the private, coordinated purposes and their transformation to pedagogical tasks.

The purpose of pedagogical activity can be classified by the following bases:

1) hierarchy (primary, derivative, final);

2) difficulties (simple, difficult); 
3) the importance (defining, subordinated, minor);

4) procedural value (motivation, understanding of a task, achievement of result, an assessment of the received result).

The hierarchy is more whole, the taxonomy of tasks is characteristic for any activity. But for pedagogical activity especially important accurate understanding of this hierarchy of the tasks purposes owing to special complexity and discrepancy of pedagogical process.

The overall objective of vocational training which consists in formation of the expert capable to creative transformation of a field of activity, breaks up to two private: formation of system of professional knowledge and abilities, and also developments of the identity of the modern expert of an average link.

The most important structural elements in pedagogical activity of the teacher are tools of its own work. They are made by knowledge and abilities. The structure of knowledge of the teacher includes system of special, pedagogical, psychological and methodical knowledge.

\section{Conclusion}

Special knowledge of the teacher is subdivided into knowledge of the theory of science and practical knowledge of features of production.

Pedagogical knowledge assumes knowledge of features of activity of pedagogical system, accurate understanding of an ultimate goal of the training and education which is trained.

The system of psychological knowledge includes knowledge of regularities of training and education on average vocational training taking into account the features which are trained and nature of interaction of structural elements of pedagogical system of vocational school. An important structural element of psychological knowledge of the teacher is the knowledge to them specific and typological features of the personality and in this regard knowledge of psychological features of course of its activity as teacher and as scientist (Makhmutov, Ibragimov, 1993).

The structure of methodical knowledge of the teacher includes knowledge of methods and methodical methods of teaching taking into account specifics of the subject and a method of education taking into account the level of good breeding of the trained different courses and different offices. Special relevance acquires knowledge of essence of modern pedagogical technologies, conditions of their application in pedagogical process now. As a result of the carriedout analysis of the theory and practice of professional education it is necessary to focus attention that the system of average vocational training will be dynamic, flexible if its subsystems are capable to change provisions relatively each other and are ready to change. To study structure and the content of process of training of future experts means, to open the most important party of essence of preparation, and also the mechanism of development and a functioning of all system of technical and professional education of the Republic of Kazakhstan.

\section{References}

A state program of development of technical and professional education in the Republic of Kazakhstan for 2008-2012. Astana, 2008.

Bespal'ko V.P. The terms of educational technology. Moscow: Pedagogy, 1989.

Chernilevsky O.V. "Didactic technology in higher education" .- M: -2002.

Grebyonkina L.K., Antsiperova of N. S. Tekhnologiya of administrative activity of the deputy principal.Moscow, "Pedagogical search", 2000.

Kashlev S.S. "Modern technologies of educational process." Minsk, 2002.

Makhmutov M.I., Ibragimov G.I. Pedagogical technologies of development thinking. - Kazan, 1993.

Selevko G. K. Modern educational technologies. Moscow: National education, 1998.

The law of the Republic of Kazakhstan "About education". Astana, 2007. 